\title{
Elemental fingerprints of otoliths of fish may distinguish estuarine 'nursery' habitats
}

\author{
Bronwyn M. Gillanders*, Michael J. Kingsford
}

School of Biological Sciences A08, University of Sydney, New South Wales 2006, Australia

\begin{abstract}
The elemental fingerprints or composition of otoliths of fish may provide a natural tag of the 'nursery' habitat of juvenile fish. The natural tag could then be used to determine the 'nursery' habitat of adult fish found on coastal reefs. We collected juvenile Pelates sexlineatus from 2 to 5 sites within each of 7 estuaries to determine whether elemental composition of otoliths differed among estuaries and among sites within estuaries. In addition, fish were collected in 2 successive years to determine whether temporal differences may be found in elemental fingerprints that could then confound subsequent assignment of adults to 'nursery' estuaries. Significant differences in elemental fingerprints ( $\mathrm{Sr}, \mathrm{Ba}$ and $\mathrm{Mn}$ ) were found within and among estuaries, but there was often an interaction with time suggesting that there were differences among estuaries/sites but the difference varied between times. Quadratic discriminant functions (QDFs) generated to discriminate among estuaries suggested that the QDFs calculated from a single year class were more successful at assigning fish to the correct estuary than either (1) QDFs based on both years combined or (2) using the QDFs generated from the first year class to classify the second year class. Small-scale variability among sites within an estuary suggested that for an estuarine fishery we may be able to classify fish to their site of origin; this warrants further investigation. Adult fish from a coastal fishery can now be assigned to their 'nursery' estuary by analysing the juvenile region of their otoliths, provided that discriminant functions are generated from the appropriate year class of recruits.
\end{abstract}

KEY WORDS: Estuarine nursery area $\cdot$ Otolith microchemistry · Trace elements

- Resale or republication not permitted without written consent of the publisher

\section{INTRODUCTION}

Estuarine 'nursery' areas are thought to be of crucial importance for sustaining stocks of fish. It is generally argued that juvenile fish recruit to estuarine habitats and then move to coastal reefs at greater sizes and ages (Bell \& Worthington 1993). Many studies have shown that juveniles of a number of species occur in large numbers in estuarine habitats (e.g. Pollard 1984, Bell \& Pollard 1989), but their adults are frequently found in open coastal environments. Despite the occurrence of adults on coastal reefs and juveniles in estuaries, there is little unequivocal evidence that estuarine habitats sustain populations of coastal reef fishes, especially given that many studies focus only on estu-

*E-mail: bronwyn@bio.usyd.edu.au aries with no sampling of open coastal environments. We do not know the proportion of individuals in harvested populations that may have spent time in different estuaries as juveniles and whether 1 or a few estuaries are making substantial contributions to maintaining local stocks of fish.

The best evidence for movement of fish has been observations of recognisable or tagged fish shifting from one place to another. Tagging of fish in estuarine habitats is difficult due to the small size of fish in estuaries and the high rates of mortality during the early life history stages. These logistical difficulties combined with the possibility that tagging may influence movements of fish has called attention to the need for alternative methods. Recent studies suggest that the elemental composition of the otoliths offers a powerful approach to determining the movements of marine fish (e.g. Campana et al. 1995, Gillanders \& Kingsford 1996, Thorrold et al. 1997). 
Otoliths form by the addition of alternating layers of protein and calcium carbonate (usually aragonite). As these layers are deposited, it has been suggested that ions, in the endolymph surrounding the otolith, may substitute for $\mathrm{Ca}$, bind to the protein or be trapped in the spaces between the calcium carbonate and protein matrices (Dove et al. 1996, Dove \& Kingsford 1998). Once the material in otoliths is deposited it is unlikely to be resorbed or reworked, because otoliths are acellular (Campana \& Neilson 1985). The chemical composition of the otolith is thought to reflect the physical and chemical characteristics of the water mass in which the fish is found, although it may not necessarily track ambient conditions directly (Kalish 1989, Fowler et al. 1995b). There is likely to be a closer relationship between ambient water chemistry and concentration in the otolith for some elements than for others, due to the properties of the element itself. Differences in water chemistry between estuaries may occur due to differences in temperature, salinity, freshwater input and anthropogenic impacts, thereby enabling the chemical composition of the juvenile portion of the otolith to reflect the estuary in which the fish spent its juvenile life. Differences in the chemical composition of layers within the otolith will, therefore, indicate past environments inhabited by fish and patterns of movement that could then be related to the age of the fish.

The chemical composition of otoliths has been used to distinguish periods of freshwater and marine residence of individual diadromous fish, and to distinguish freshwater and salt water fish from within the same species (e.g. Kalish 1990, Secor 1992). Chemical analyses of otoliths have also been used to distinguish stocks or sub-populations of adult fish within marine species (Edmonds et al. 1989, 1991, 1992, Campana et al. 1994, Campana \& Gagne 1995), but only recently have differences in otolith chemistry been used to detect movement in non-diadromous fish (e.g. Campana et al. 1995, Gillanders \& Kingsford 1996). Recent studies have focused on whether otolith chemistry of juvenile fish varies between different juvenile habitats (e.g. Gillanders \& Kingsford 1996, Thorrold et al. 1997, 1998a,b). Few studies have determined whether elemental fingerprints determined in one year are reflective of other years (but see Milton et al. 1997).

In this study we investigated the utility of trace elements in otoliths for determining the proportion of adult fish in coastal environments that may have recruited to adult populations from different estuaries. The specific aims were to (1) determine if otoliths of juvenile fish show differences in elemental composition or fingerprints (sensu Campana et al. 1994) among estuaries and among sites within estuaries, (2) determine whether elemental fingerprints were similar in the otoliths of fish collected in successive years. Based on these data, we also wanted to determine whether the elemental fingerprints of otoliths could subsequently be used to estimate the relative contribution of different estuaries to the coastal fishery or of estuarine sites to an estuarine fishery. The species chosen for this study was the trumpeter Pelates sexlineatus (Terapontidae), which is common in all of the estuaries we sampled along the coast of New South Wales, Australia. Adults are found in multiple environments including estuaries, coastal reefs and the shelf.

\section{MATERIALS AND METHODS}

Juvenile trumpeter Pelates sexlineatus were collected in each of the 2 years (1998 and 1999). Fish were collected from 2 sites in each of 7 estuaries along the east coast of Australia to determine variation in elemental fingerprints among estuaries (Fig. 1). To determine variation in elemental fingerprints within estuaries, 2 to 3 extra sites were also sampled within each of 3 estuaries (Botany Bay, Brisbane Waters and Port Stephens). Within each estuary, sites were separated by hundreds of metres to $6 \mathrm{~km}$. Fish were collected by beach seine nets and were stored on ice in the field before being frozen on return to the laboratory (Table 1).

Pelates sexlineatus recruits to estuaries at a size of 10 to $20 \mathrm{~mm} \mathrm{SL}$, whereas the average length of fish used in this study was $50 \mathrm{~mm}$ SL (Table 1). Based on cohort analyses, it was estimated that fish of this size would have spent 4 to 6 mo in the estuary. It was assumed that this amount of time was sufficient for the incorporation of an elemental signature from the estuarine environment. It was also assumed that fish of similar sizes from different estuaries would have spent approximately the same amount of time in estuaries. In addition, the mean weight of otoliths used in the analyses $(1.28 \mathrm{mg})$ was approximately 10 times the mean weight of fish that had recently settled $(0.129 \mathrm{mg}, \mathrm{n}=15)$, again suggesting that there was sufficient incorporation of elemental fingerprint since time of settlement.

In the laboratory, the standard length (SL) of each fish was measured, and the sagittal otoliths were removed, cleaned of adhering tissue in Milli-Q water, air-dried and placed in eppendorf microcentrifuge tubes. Otoliths were weighed on a microbalance (to $0.001 \mathrm{mg}$ ), cleaned in $1 \%$ nitric acid for 5 to $10 \mathrm{~s}$, rinsed in Milli-Q water and placed in acid-washed polycarbonate tubes ready for analysis.

Samples were dissolved in nitric acid for at least $1 \mathrm{~h}$ inside a laminar flow cabinet. They were then diluted with Milli-Q water to $1 \% \mathrm{HNO}_{3}$. Blank samples were prepared in the same manner, but no otolith was present; these were used for blank corrections and to cal- 

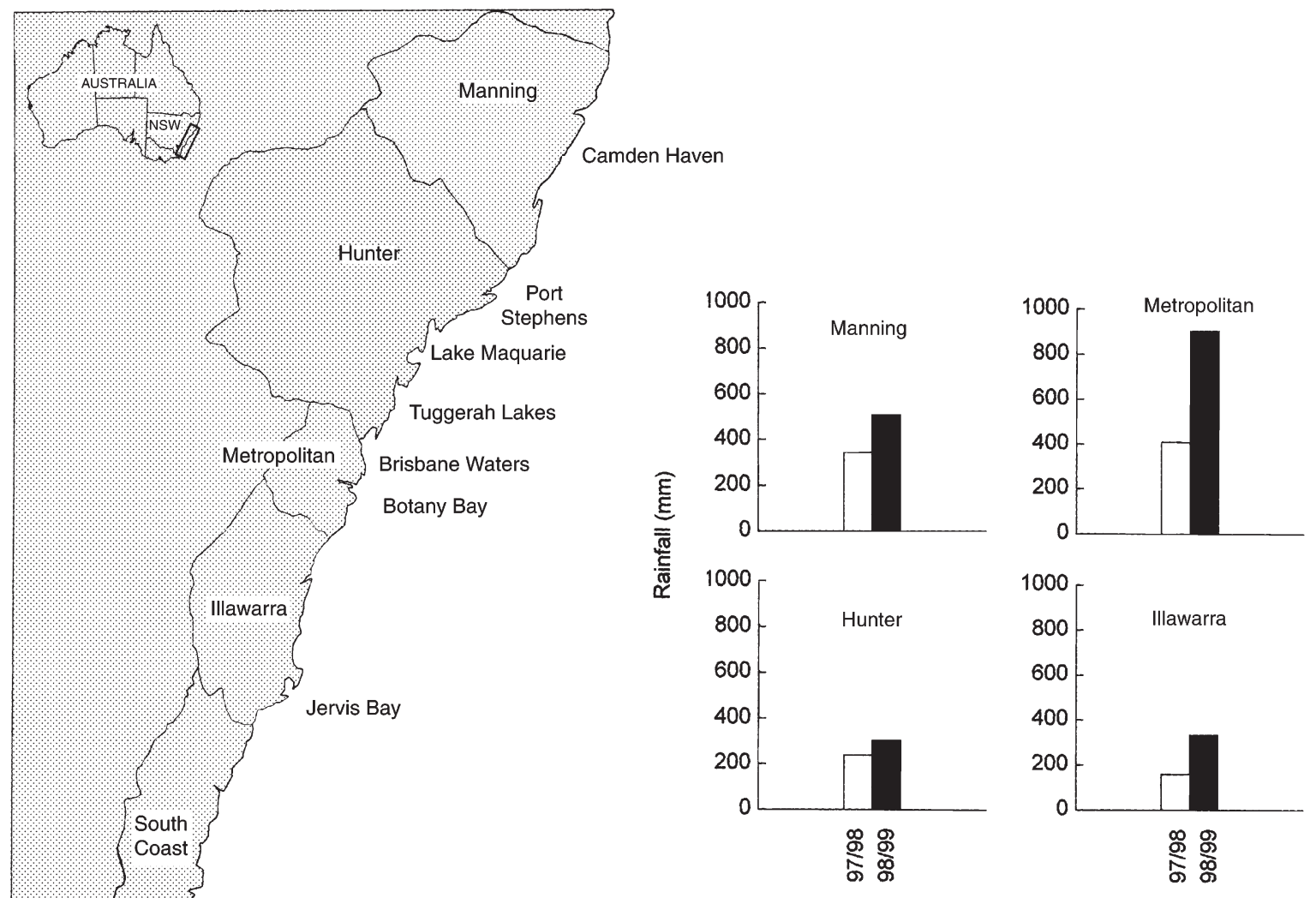

Fig. 1. Location of estuaries where juveniles of Pelates sexlineatus were collected. Total rainfall between November and February of each recruitment season for each meteorological region is shown

culate limits of detection. Spiked samples of otolith were also analysed every 10 samples to assess instrument drift and recovery. Samples were analysed by solution-based inductively coupled plasma-mass spectrometry (ICP-MS; Perkin Elmer SCIEX ELAN 5000). All elements were analysed using standards that were matrix-matched (i.e. addition calibration), except $\mathrm{Sr}$, which was analysed using standards made up in $1 \%$ $\mathrm{HNO}_{3}$ (i.e. external calibration). Additional details regarding ICP-MS analyses can be found in Gillanders \& Kingsford (1996). Preliminary analyses suggested that 7 elements ( $\mathrm{Mg}, \mathrm{Mn}, \mathrm{Cu}, \mathrm{Zn}, \mathrm{Sr}, \mathrm{Ba}$ and $\mathrm{Pb}$ ) were detectable in otoliths of juvenile Pelates sexlineatus using ICP-MS and these elements were chosen for analyses.

Detection limits, which were calculated from the concentration of analyte yielding a signal equivalent to 3 times the standard deviation of the blank signal, for each of the elements were: $0.96 \mathrm{~g}^{-1}(\mathrm{Mg}), 0.04 \mathrm{\mu g} \mathrm{g}^{-1}$ (Mn), $1.05 \mu \mathrm{g} \mathrm{g}^{-1}(\mathrm{Cu}), 1.77 \mu \mathrm{g} \mathrm{g}^{-1}(\mathrm{Zn}), 0.21 \mu \mathrm{g} \mathrm{g}^{-1}(\mathrm{Sr})$, $0.04 \mu \mathrm{g} \mathrm{g}^{-1}(\mathrm{Ba})$, and $0.24 \mu \mathrm{g} \mathrm{g}^{-1}(\mathrm{~Pb}) . \mathrm{Cu}, \mathrm{Zn}$ and $\mathrm{Pb}$ were frequently below detection limits for otolith samples and were, therefore, removed from subsequent analyses. Mean estimates of precision (\% RSD, relative standard deviation) based on replicate measurements within otolith samples were: 33.2\% (Mg), $2.5 \%$ (Mn), $1.5 \%(\mathrm{Sr})$, and $2.1 \%(\mathrm{Ba}) . \mathrm{Mg}$ showed poor precision and was eliminated from subsequent analyses. Mean recovery of spiked samples for the remaining elements was: $88 \%(\mathrm{Mn}), 106 \%(\mathrm{Sr})$, and $86 \%(\mathrm{Ba})$.

Univariate and multivariate techniques were used to test hypotheses concerning individual elements and multi-element fingerprints of Pelates sexlineatus. Spatial and temporal variation in otolith chemistry was analysed by analysis of variance (ANOVA) for each element ( $\mathrm{Mn}, \mathrm{Sr}$ and $\mathrm{Ba})$. To determine whether significant differences were found among estuaries, each year of data was analysed separately (2-factor ANOVA, site nested within estuary). The 2 yr of data were then analysed by a 3-factor mixed model ANOVA (year, estuary and site nested within estuary) to determine whether significant differences were found between years. In this design a test was not possible for estuary. Where there was a significant year $x$ estuary interaction this was not a problem, and if the year $\times$ estuary interaction or site nested within estuary 
Table 1. Summary information for Pelates sexlineatus collected for comparisons of elemental fingerprints at (a) large-scale among estuaries and (b) small-scale within estuary. Shown are the estuaries and sites where fish were collected, dates of collection $(\mathrm{mo} / \mathrm{yr})$, mean standard length $(\mathrm{SL} \pm \mathrm{SE}[\mathrm{mm}])$ and mean otolith weight $(\mathrm{OW} \pm \mathrm{SE}[\mathrm{mg}])$

\begin{tabular}{|c|c|c|c|c|c|c|c|}
\hline Estuary & Site & Date & Mean SL & Mean OW & Date & Mean SL & Mean OW \\
\hline \multicolumn{8}{|c|}{ (a) Large-scale among estuary ( $n=5$ fish per site) } \\
\hline \multirow[t]{2}{*}{ Camden Haven $(\mathrm{CH})$} & 1 & $02 / 98$ & $55.0 \pm 5.4$ & $1.58 \pm 0.31$ & 02/99 & $36.8 \pm 0.8$ & $0.74 \pm 0.04$ \\
\hline & 2 & $02 / 98$ & $54.2 \pm 2.9$ & $1.39 \pm 0.12$ & 02/99 & $51.0 \pm 7.7$ & $1.41 \pm 0.44$ \\
\hline \multirow[t]{2}{*}{ Port Stephens (PS) } & 2 & $02 / 98$ & $47.2 \pm 3.2$ & $1.27 \pm 0.18$ & 02/99 & $41.2 \pm 3.6$ & $0.92 \pm 0.18$ \\
\hline & 3 & 02/98 & $45.4 \pm 4.3$ & $1.09 \pm 0.21$ & 02/99 & $45.6 \pm 2.7$ & $1.04 \pm 0.12$ \\
\hline \multirow{2}{*}{ Lake Macquarie (LM) } & 1 & $02 / 98$ & $36.0 \pm 0.7$ & $0.64 \pm 0.03$ & 02/99 & $37.8 \pm 2.4$ & $0.66 \pm 0.08$ \\
\hline & 2 & 02/98 & $54.8 \pm 2.2$ & $1.41 \pm 0.11$ & 02/99 & $54.6 \pm 4.9$ & $1.30 \pm 0.21$ \\
\hline \multirow[t]{2}{*}{ Tuggerah Lakes (TL) } & 1 & $02 / 98$ & $56.8 \pm 3.2$ & $1.61 \pm 0.16$ & 02/99 & $36.0 \pm 1.0$ & $0.78 \pm 0.06$ \\
\hline & 2 & $02 / 98$ & $41.4 \pm 0.9$ & $0.86 \pm 0.02$ & 02/99 & $42.0 \pm 1.1$ & $0.94 \pm 0.06$ \\
\hline \multirow[t]{2}{*}{ Brisbane Waters (BW) } & 2 & 03/98 & $51.6 \pm 4.7$ & $1.55 \pm 0.29$ & 02/99 & $40.2 \pm 1.5$ & $0.84 \pm 0.06$ \\
\hline & 4 & 03/98 & $48.4 \pm 1.8$ & $1.16 \pm 0.08$ & 02/99 & $43.8 \pm 0.5$ & $0.88 \pm 0.02$ \\
\hline \multirow[t]{2}{*}{ Botany Bay (BB) } & 2 & $02 \& 03 / 98$ & $52.0 \pm 1.2$ & $1.40 \pm 0.11$ & $02 \& 03 / 99$ & $50.6 \pm 6.5$ & $1.32 \pm 0.31$ \\
\hline & 4 & $02 \& 03 / 98$ & $53.6 \pm 0.6$ & $1.29 \pm 0.06$ & 03/99 & $50.2 \pm 1.0$ & $1.31 \pm 0.08$ \\
\hline \multirow[t]{2}{*}{ Jervis Bay (JB) } & 1 & $03 \& 04 / 98$ & $54.8 \pm 1.9$ & $1.54 \pm 0.11$ & 03/99 & $29.0 \pm 1.1$ & $0.40 \pm 0.03$ \\
\hline & 2 & $03 \& 04 / 98$ & $43.0 \pm 3.3$ & $1.03 \pm 0.17$ & 03/99 & $35.9 \pm 1.3$ & $0.68 \pm 0.05$ \\
\hline \multicolumn{8}{|c|}{ (b) Small-scale within estuary ( $n=5$ for PS and BW and $n=7$ for BB per site) } \\
\hline \multirow[t]{4}{*}{ Port Stephens (PS) } & 1 & $02 / 98$ & $61.2 \pm 6.5$ & $2.20 \pm 0.51$ & 02/99 & $61.2 \pm 5.5$ & $1.90 \pm 0.31$ \\
\hline & 2 & $02 / 98$ & $47.2 \pm 3.2$ & $1.27 \pm 0.18$ & 02/99 & $41.2 \pm 3.6$ & $0.92 \pm 0.18$ \\
\hline & 3 & $02 / 98$ & $45.4 \pm 4.3$ & $1.09 \pm 0.21$ & 02/99 & $45.6 \pm 2.7$ & $1.04 \pm 0.12$ \\
\hline & 4 & $02 / 98$ & $57.4 \pm 1.7$ & $1.99 \pm 0.11$ & 02/99 & $55.0 \pm 4.4$ & $1.73 \pm 0.25$ \\
\hline \multirow[t]{4}{*}{ Brisbane Waters (BW) } & 1 & $03 / 98$ & $59.6 \pm 5.7$ & $1.99 \pm 0.38$ & $02 / 99$ & $41.8 \pm 1.4$ & $0.82 \pm 0.06$ \\
\hline & 2 & 03/98 & $51.6 \pm 4.7$ & $1.55 \pm 0.29$ & 02/99 & $40.2 \pm 1.5$ & $0.84 \pm 0.06$ \\
\hline & 3 & 03/98 & $61.0 \pm 3.5$ & $2.08 \pm 0.33$ & 02/99 & $41.8 \pm 1.4$ & $0.80 \pm 0.06$ \\
\hline & 4 & 03/98 & $48.4 \pm 1.8$ & $1.16 \pm 0.08$ & 02/99 & $43.8 \pm 0.5$ & $0.88 \pm 0.02$ \\
\hline \multirow[t]{5}{*}{ Botany Bay (BB) } & 1 & 03/98 & $47.3 \pm 0.7$ & $1.03 \pm 0.02$ & $01 \& 02 / 99$ & $47.6 \pm 1.9$ & $0.97 \pm 0.08$ \\
\hline & 2 & $03 \& 04 / 98$ & $50.9 \pm 1.1$ & $1.31 \pm 0.10$ & $02 \& 03 / 99$ & $47.3 \pm 5.0$ & $1.19 \pm 0.23$ \\
\hline & 3 & $02 \& 03 / 98$ & $54.0 \pm 1.0$ & $1.48 \pm 0.04$ & $01 \& 02 / 99$ & $51.9 \pm 0.8$ & $1.19 \pm 0.06$ \\
\hline & 4 & $02 \& 03 / 98$ & $51.7 \pm 1.3$ & $1.25 \pm 0.06$ & 03/99 & $49.4 \pm 0.8$ & $1.27 \pm 0.06$ \\
\hline & 5 & $02 \& 03 / 98$ & $56.9 \pm 2.1$ & $1.84 \pm 0.17$ & $02 \& 03 / 99$ & $50.7 \pm 0.7$ & $1.31 \pm 0.05$ \\
\hline
\end{tabular}

terms were not significant at $p=0.25$, one of these terms was eliminated from the model resulting in a test for estuary (Underwood 1997). Analyses of small-scale spatial variability were done on each of the 3 estuaries separately (2-factor ANOVAs, site and year). All factors were treated as random terms in the ANOVA models. All analyses were made on $\ln (x+1)$-transformed data. The assumption of homogeneity of variance was tested prior to each analysis using Cochran's $C$-test (Winer et al. 1991). When data remained heterogeneous after transformation, analyses were still performed as ANOVA is robust to departures from assumptions where data are balanced and samples are relatively large (Underwood 1997).

Multi-element fingerprints were analysed by nonparametric analysis of similarity (ANOSIM) permutation tests (Clarke 1993). Separate analyses were performed on each year of data for all 7 estuaries and on each of the 3 estuaries for the small-scale spatial data. For the 7 estuaries it was not possible to have site nested within estuary as a term in the model, because the small number of possible permutations did not allow strong infer- ences to be made. These data were therefore analysed as 1-factor (estuary) designs. Two-factor (year and site) designs were used for the individual estuaries but only the main factors could be tested, i.e. it was not possible to test for an interaction between year and site (Clarke 1993). Triangular dissimilarity matrices were calculated using Euclidean dissimilarity measures on double square root transformed data. The ANOSIM permutation test was used to assess the significance of differences among estuaries for each year of data, and between years and among sites for each of the 3 estuaries. A Global $R$ value (= test statistic) was produced based on average dissimilarities within replicate samples and average dissimilarities between different samples. The Global $R$ value can be tested by evaluating random rearrangements (permutations) of the data (see Clarke 1993); in this case the procedure was repeated 5000 times. Multiple comparisons on individual pairs were also carried out in the same way. All analyses were performed using PRIMER (Plymouth Routines in Marine Environmental Research) programs (copyright M. R. Carr and K. R. Clarke, Marine Biological Laboratory, Plymouth, UK). 
Non-metric multidimensional scaling (nMDS) plots were used as the ordination method. The dissimilarity matrix was calculated using Euclidean distances. The goodness of fit of the data points in the nMDS was measured by the stress coefficient, where stress tends to zero when data are perfectly represented (Clarke 1993). The final nMDS plot is only determined to within an arbitrary orientation, reflection, location and scale, which explains the absence of axis scales and labels in the figures (Clarke 1993).

Quadratic discriminant function analysis (DFA) was used to determine the ability of elemental fingerprints to correctly record the recruitment estuary or site of juvenile Pelates sexlineatus. Quadratic DFA was selected because it does not require the assumption of equal covariance matrices (Engelman 1998). Quadratic functions were determined in SYSTAT; these functions were then used to classify fish according to recruitment estuary or site within an estuary using a jackknife (or leave-one-out) method and the accuracy of these classifications determined as the percentage correct.

\section{RESULTS}

\section{Large-scale spatial variability among estuaries}

Juvenile trumpeter collected from the 7 estuaries ranged in size from 26 to $78 \mathrm{~mm}$ (Table 1). There were no significant differences in either standard length (ANOVA, $F_{6,7}=0.898, \mathrm{p}>0.5$ ) or otolith weight (ANOVA, $F_{6,7}=0.895, \mathrm{p}>0.5$ ) among estuaries, although there was a significant year $\times$ site nested within estuary interaction (ANOVA, SL: $F_{7,112}=3.947$, $\mathrm{p}<0.01$; otolith weight: $F_{7,112}=3.175, \mathrm{p}<0.01$ ), which indicated that differences in standard length or otolith weight occurred but they were not consistent between years and among sites. The greatest difference in size of fish or otolith weight was for fish collected from Site 1 in Jervis Bay, where in the second year fish of a similar size to that collected in the first year could not be found (see Table 1). With the exception of Site 1 in Jervis Bay, differences in standard length between sites within an estuary or between years for the same site were less than $21 \mathrm{~mm}$ (Table 1). We consider the effect sizes to be so small and spatially inconsistent that any differences in standard length or otolith weight would not confound our interpretation of elemental patterns.

Significant differences were found in the otolith chemistry of juveniles collected from different estuaries. Manganese showed significant differences among estuaries in both years, although this was largely attributable to high amounts of $\mathrm{Mn}$ in otoliths of fish collected from Tuggerah Lakes in 1998 and Tuggerah Lakes and Camden Haven in 1999 (Fig. 2a, Table 2a). Significant differences were found between sites within an estuary in both years. The magnitude of differences and in some cases rank concentrations of elements at sites within estuaries varied between years leading to a significant year $\times$ site nested within estuary interaction in the 3 -factor ANOVA model that incorporated the 2 years of data (Fig. 2a, Table 2b). There was also a significant difference among estuaries (Table 2b).

No differences in $\mathrm{Sr}$ and $\mathrm{Ba}$ concentration were found among estuaries (Fig. 2b,c; Table 2a). Large differences were, however, found between sites within some estuaries resulting in a significant site nested within estuary term (Fig. 2b,c; Table 2a). The magnitude of differences in concentration, and sometimes rank concentration, varied between years at sites within estuaries (Fig. 2b,c; Table 2b). There was also a significant year $\times$ estuary interaction for $\mathrm{Ba}$, suggesting that there were differences among estuaries but that magnitude varied between years (Fig. 2c, Table 2b).

Elemental fingerprints of otoliths showed significant variation among estuaries and at sites within estuaries (Fig. 3). Non-parametric ANOSIMs detected significant differences among estuaries for both years (1998 Global $R=0.374, \mathrm{p}<0.001 ; 1999$ Global $R=0.464$, $\mathrm{p}<0.001)$. Pairwise a posteriori tests showed that in 1998 Port Stephens was similar to Brisbane Waters and Botany Bay was similar to Jervis Bay, but all other estuaries differed (Fig. 3a). Tuggerah Lakes was clearly separated from the other 6 estuaries in 1998 and also showed clear differences among sites (Fig. 3a). The nMDS plot showed that in 1998 the remaining 6 estuaries could be grouped into northern (Camden Haven), central (Port Stephens, Lake Macquarie and Brisbane Waters) and southern (Botany Bay and Jervis Bay) estuaries (Fig. 3a). In 1999, pairwise a posteriori tests showed that Lake Macquarie was similar to Brisbane Waters, but all other estuaries differed (Fig. 3b). The nMDS suggested that Camden Haven and Tuggerah Lakes showed some overlap but remained separated from the other estuaries (Fig. 3b). Individual sites from other estuaries could also be distinguished (Fig. 3b).

When both years of data were combined, the nMDS plot showed separation between years for some estuaries (e.g. Camden Haven, Port Stephens and Botany Bay), but there was also overlap between years for other estuaries (e.g. Lake Macquarie, Tuggerah Lakes and Brisbane Waters) (Fig. 3c). These data suggest that elemental fingerprints of juveniles need to be determined each year if the elemental fingerprints of adults are to be used to determine the estuary in which they 

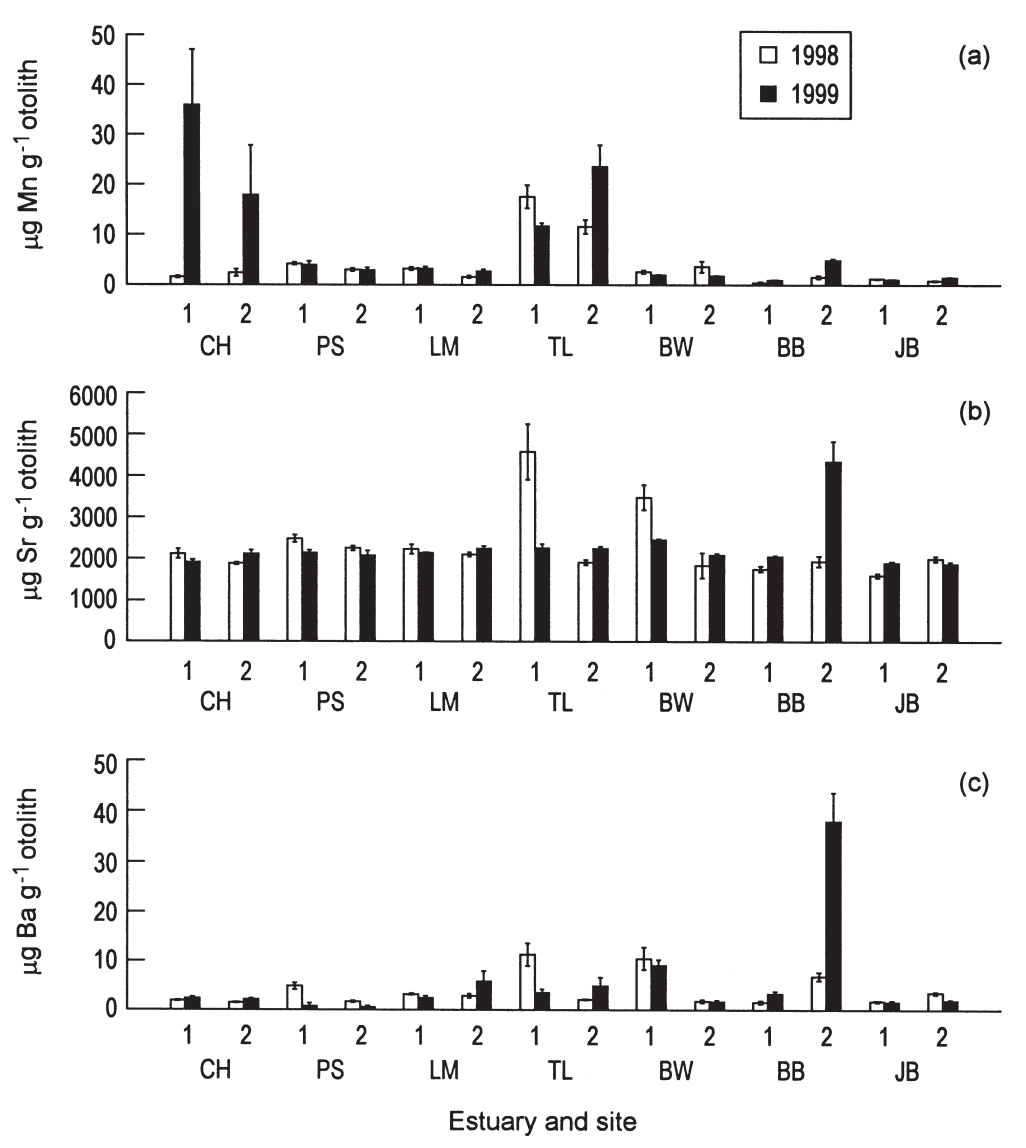

Fig. 2. Pelates sexlineatus. Mean $( \pm \mathrm{SE})$ concentration of (a) Mn, (b) Sr and (c) Ba in otoliths of juvenile trumpeter collected in 1998 and 1999 from 2 sites within each of 7 estuaries along the coast of New South Wales, Australia. The estuaries were Camden Haven (CH), Port Stephens (PS), Lake Macquarie (LM), Tuggerah Lakes (TL), Brisbane Waters (BW), Botany Bay (BB) and Jervis Bay (JB)

recruited. The year class of the adults will need to be considered and adult fingerprints matched with juvenile fingerprints of the $0+$ year.

Quadratic DFA was used to determine the ability of elemental fingerprints to classify correctly juvenile fish to their recruitment-estuaries. When elemental fingerprints from individual years were used to classify fish, success rates ranged from 50 to $100 \%$ (Table 3a,b). Fish collected from Lake Macquarie were most difficult to classify as having come from Lake Macquarie in both years (classification success 60 and $50 \%$ for 1998 and 1999 respectively), although in 1998 two other estuaries also had success rates of $60 \%$. Fish collected from Tuggerah Lakes in 1998 were correctly classified to that estuary. When data from fish collected in both years were combined and a new classification matrix determined, success rates generally decreased, suggesting that fish from only 1 year class should be used for determining classification matrices (Table 3c). Like- wise, when the classification matrix from fish collected during 1998 was used to classify fish collected during 1999, success rates were 0 to $90 \%$ (Table 3d). Fish collected in Tuggerah Lakes were most likely to be correctly classified and those collected in Botany Bay were the least likely to be correctly classified, suggesting that Tuggerah Lakes showed least variability in elemental fingerprints between years and Botany Bay showed most variability.

\section{Small-scale spatial variability within estuaries}

Juvenile fish were collected from additional sites (separated by hundreds of metres to kilometres) in each of 3 estuaries (Port Stephens, Brisbane Waters and Botany Bay) to test for small-scale variability in otolith chemistry within an estuary and to determine whether among-site variability was sufficient to allow accurate classification to their recruitment sites. There was no significant difference in standard length among sites or between years. Otolith weight did not vary among sites or between years for 2 of the 3 estuaries (exception Brisbane Waters, year $\times$ site interaction, $F_{1,3}=19.3, \mathrm{p}<$ 0.05).

There was significant variability among estuaries in terms of differences seen within an estuary for the individual elements (Fig. 4). For example, Mn in otoliths of juvenile fish in Brisbane Waters did not differ among sites or between years, but in Botany Bay greater amounts of Mn occurred in otoliths in 1999 compared to 1998, but the magnitude of difference varied among sites (year $\times$ site interaction, $\mathrm{p}<0.05$ ) (Fig. $4 \mathrm{a}$, Table 4). Sr and Ba, however, occurred in greater concentrations in otoliths of fish collected from Port Stephens in 1998 than 1999, but in the case of $\mathrm{Ba}$ the magnitude of variation between years differed among sites (Fig. $4 \mathrm{~b}, \mathrm{c}$ ). There was a trend for greater amounts of $\mathrm{Sr}$ and Ba in otoliths of fish from Brisbane Waters in 1998, but the difference between years varied by site (year $\times$ site interaction, $\mathrm{p}<0.05$ ) (Fig. 4b,c, Table 4). In Botany Bay, Ba was always lowest for fish collected from Site 2 in both years. Other sites showed no consistent pattern for amounts of $\mathrm{Ba}$ in otoliths, although differences among sites and between years were found (Fig. 4c, Table 4). Lower levels of Sr in otoliths of fish in 2 of the 3 estuar- 
Table 2. Results of ANOVA on individual elements in otoliths of juvenile trumpeter for (a) each of 2 years and (b) both years combined for fish collected from 2 sites in each of 7 estuaries. Cochran's tests were used to test homogeneity of variances; the data remained heterogeneous after transformation for all analyses involving $\mathrm{Sr}$, and for $\mathrm{Mn}$ in 1999 and both years combined. All analyses were made on $\ln (x+1)$ transformed data. $p$-values of 0.000 indicate $\mathrm{p}<0.001$

\begin{tabular}{|c|c|c|c|c|c|c|c|}
\hline \multirow{2}{*}{ Source } & \multirow[b]{2}{*}{$\mathrm{df}$} & \multicolumn{3}{|c|}{$1998-$} & \multicolumn{3}{|c|}{-1999} \\
\hline & & MS & $F$ & $\mathrm{p}$ & MS & $F$ & $\mathrm{p}$ \\
\hline \multicolumn{8}{|c|}{ (a) Each of two years } \\
\hline \multicolumn{8}{|c|}{ Mn } \\
\hline Estuary & 6 & 4.958 & 15.15 & 0.001 & 6.486 & 5.75 & 0.019 \\
\hline Site (Estuary) & 7 & 0.327 & 4.95 & 0.000 & 1.129 & 3.71 & 0.002 \\
\hline Error & 56 & 0.066 & & & 0.305 & & \\
\hline \multicolumn{8}{|l|}{$\mathrm{Sr}$} \\
\hline Estuary & 6 & 0.289 & 0.63 & 0.706 & 0.201 & 0.99 & 0.496 \\
\hline Site (Estuary) & 7 & 0.460 & 12.58 & 0.000 & 0.203 & 24.36 & 0.000 \\
\hline Error & 56 & 0.067 & & & 0.008 & & \\
\hline \multicolumn{8}{|l|}{ Ba } \\
\hline Estuary & 6 & 0.693 & 0.35 & 0.889 & 4.511 & 1.83 & 0.225 \\
\hline Site (Estuary) & 7 & 1.975 & 32.08 & 0.000 & 2.471 & 18.27 & 0.000 \\
\hline Error & 56 & 0.062 & & & 0.135 & & \\
\hline Source & & df & M & & $F$ & & $\mathrm{p}$ \\
\hline \multicolumn{8}{|c|}{ (b) Both years combined } \\
\hline \multicolumn{8}{|l|}{ Mn } \\
\hline Year & & 1 & 3.7 & & 1.83 & & 0.225 \\
\hline Estuary & & 6 & 9.3 & & 4.57 & & 0.044 \\
\hline Year $\times$ Estuary & & 6 & 2.0 & 56 & 3.22 & & 0.076 \\
\hline Site (Estuary) & & 7 & 0.8 & & 1.28 & & 0.376 \\
\hline Year $\times$ Site $($ Es & uary) & 7 & 0.6 & & 3.44 & & 0.002 \\
\hline Error & & 112 & 0.1 & 85 & & & \\
\hline \multicolumn{8}{|l|}{$\mathrm{Sr}$} \\
\hline Year & & 1 & 0.0 & & 0.04 & & 0.844 \\
\hline Estuary & & 6 & 0.2 & 34 & 0.60 & & 0.728 \\
\hline Year $\times$ Estuary & & 6 & 0.2 & & 0.95 & & 0.517 \\
\hline Site (Estuary) & & 7 & 0.3 & & 1.46 & & 0.315 \\
\hline Year $\times$ Site $($ Es & uary) & 7 & 0.2 & 70 & 12.01 & & 0.000 \\
\hline Error & & 112 & 0.0 & 22 & & & \\
\hline \multicolumn{8}{|l|}{ Ba } \\
\hline Year & & 1 & 0.0 & & 0.03 & & 0.872 \\
\hline Estuary & & 6 & 3.2 & & No test & & \\
\hline Year $\times$ Estuary & & 6 & 1.9 & & 2.39 & & 0.032 \\
\hline Site (Estuary) & & 7 & 3.6 & & 4.55 & & 0.139 \\
\hline Year $\times$ Site $($ Es & uary) & 7 & 0.8 & & 8.14 & & 0.000 \\
\hline Error & & 112 & 0.0 & 98 & & & \\
\hline
\end{tabular}

ies during the second year were correlated with increased rainfall, and therefore freshwater input, in this year (Figs. $1 \& 4$ b). Botany Bay, however, showed increased $\mathrm{Sr}$ in otoliths of fish in the second year when rainfall in this region was approximately double the previous year, suggesting that other mechanisms may also play a role, for example, depth of residency (see Kingsford \& Gillanders in press).

Elemental fingerprints of otoliths of juvenile trumpeter varied between years and among sites for all 3 estuaries (Fig. 5, Table 5). nMDS plots showed some separation of sites between years, suggesting that

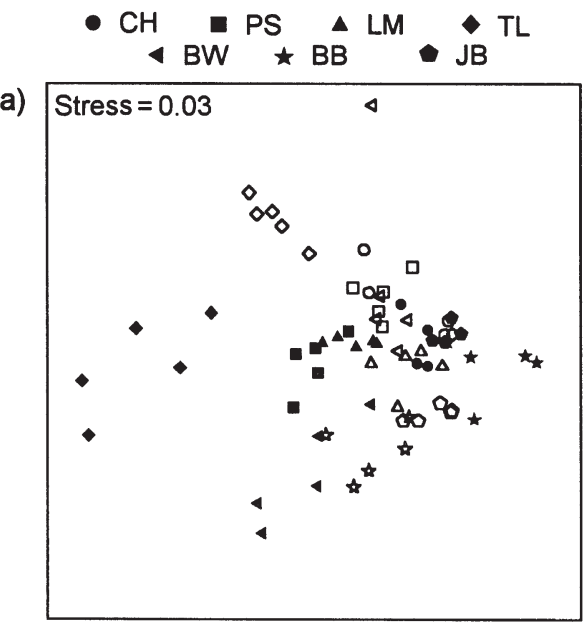

(b)

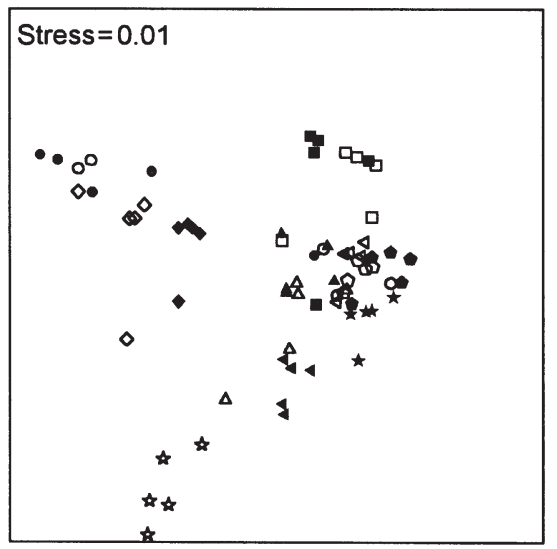

(c)

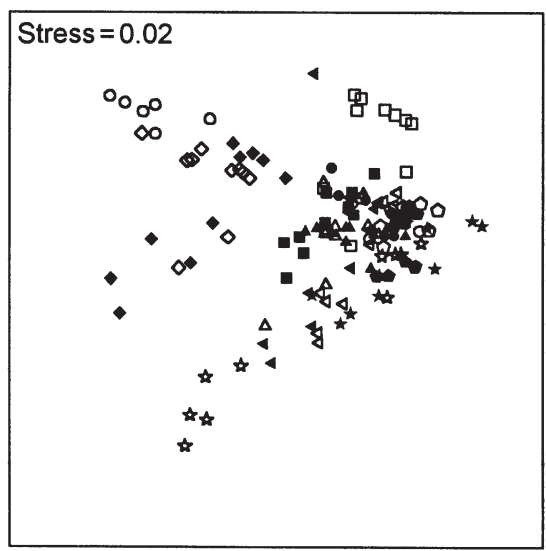

Fig. 3. MDS ordinations of multi-element fingerprints for Pelates sexlineatus collected at 2 sites in each of 7 estuaries during (a) 1998, (b) 1999 and (c) both years combined. Closed and open symbols are used to denote the 2 sites in (a) and (b) and the 2 years in (c). Stress values are shown on each plot

there may be different elemental fingerprints between years (Fig. 5). For Port Stephens individual sites were difficult to separate based on nMDS plots. The other 2 estuaries showed greater separation of individual sites within each year (Fig. 5). 
Table 3. Results of discriminant function analyses where juvenile trumpeter are classified to recruitment-estuary based on elemental fingerprints ( $\mathrm{Mn}, \mathrm{Sr}, \mathrm{Ba})$ of otoliths. The percentage of fish classified to each estuary are shown for collections made in (a) 1998, (b) and (d) 1999, and (c) both years. The discriminant functions were developed using a cross validation approach for the fish being classified in (a) to (c), or a discriminant function developed on fish collected in the previous year (d). Juveniles were collected from Camden Haven $(\mathrm{CH})$, Port Stephens (PS), Lake Macquarie (LM), Tuggerah Lakes (TL), Brisbane Waters (BW), Botany Bay (BB) and Jervis Bay (JB). Bold values indicate percent of fish correctly classified to their recruitment estuaries. Sample sizes were $n=10$ for (a), (b) and (d), and $\mathrm{n}=20$ for (c)

\begin{tabular}{|c|c|c|c|c|c|c|c|c|}
\hline \multicolumn{3}{|c|}{ From estuary: $\mathrm{CH}$} & PS & LM & TL & BW & BB & JB \\
\hline \multirow[t]{7}{*}{ (a) } & $\mathrm{CH}$ & 90 & 10 & 20 & 0 & 20 & 10 & 10 \\
\hline & PS & 0 & 90 & 10 & 0 & 10 & 0 & 0 \\
\hline & LM & 10 & 0 & 60 & 0 & 10 & 0 & 0 \\
\hline & TL & 0 & 0 & 0 & 100 & 0 & 0 & 0 \\
\hline & BW & 0 & 0 & 0 & 0 & 60 & 0 & 0 \\
\hline & BB & 0 & 0 & 10 & 0 & 0 & 80 & 30 \\
\hline & JB & 0 & 0 & 0 & 0 & 0 & 10 & 60 \\
\hline \multirow[t]{7}{*}{ (b) } & $\mathrm{CH}$ & 70 & 10 & 10 & 10 & 0 & 0 & 0 \\
\hline & PS & 0 & 70 & 0 & 0 & 0 & 0 & 0 \\
\hline & LM & 20 & 0 & 50 & 0 & 0 & 10 & 0 \\
\hline & $\mathrm{TL}$ & 0 & 0 & 0 & 90 & 0 & 0 & 0 \\
\hline & BW & 10 & 10 & 20 & 0 & 70 & 0 & 0 \\
\hline & BB & 0 & 0 & 20 & 0 & 20 & 90 & 20 \\
\hline & JB & 0 & 10 & 0 & 0 & 10 & 0 & 80 \\
\hline \multirow[t]{7}{*}{ (c) } & $\mathrm{CH}$ & 75 & 10 & 10 & 35 & 10 & 0 & 10 \\
\hline & PS & 0 & 70 & 10 & 0 & 0 & 0 & 0 \\
\hline & LM & 0 & 15 & 65 & 0 & 35 & 0 & 5 \\
\hline & $\mathrm{TL}$ & 0 & 0 & 0 & 65 & 5 & 0 & 0 \\
\hline & BW & 5 & 0 & 0 & 0 & 20 & 5 & 0 \\
\hline & BB & 0 & 0 & 5 & 0 & 30 & 60 & 5 \\
\hline & JB & 20 & 5 & 10 & 0 & 0 & 35 & 80 \\
\hline \multirow[t]{7}{*}{ (d) } & $\mathrm{CH}$ & 30 & 10 & 10 & 0 & 30 & 0 & 40 \\
\hline & PS & 0 & 70 & 10 & 0 & 0 & 0 & 0 \\
\hline & LM & 10 & 10 & 60 & 0 & 10 & 10 & 20 \\
\hline & TL & 60 & 0 & 0 & 90 & 0 & 0 & 0 \\
\hline & BW & 0 & 10 & 10 & 10 & 20 & 50 & 0 \\
\hline & BB & 0 & 0 & 10 & 0 & 40 & 0 & 20 \\
\hline & JB & 0 & 0 & 0 & 0 & 0 & 40 & 20 \\
\hline
\end{tabular}

The ability to predict correctly the site that fish had recruited to within an estuary varied among sites and between years within each estuary (Table 6). Success rates in Port Stephens ranged between 60 and 100\%. When fish collected in both years from Port Stephens were used in the DFA, the successful classification rates decreased to 50 to $70 \%$. Brisbane Waters and Botany Bay had success rates that averaged 82 and $79 \%$ respectively when fish from individual years were used in the analysis (Table 6). When fish from both years were used in the analysis, both estuaries had 1 site where classification success was relatively poor (Site 1 in Brisbane Waters and Site 1 in Botany Bay), but the remaining sites showed good classification rates.

\section{DISCUSSION}

\section{Spatial differences in elemental composition of otoliths}

The elemental composition of otoliths of juvenile trumpeter varied both within and among estuaries, as well as between the 2 years of sampling. The elemental signatures of otoliths of fish from each of the estuaries showed some overlap among estuaries, although it was generally possible to separate fish from 1 to 2 individual estuaries, as well as to separate groups of estuaries within each year. Thorrold et al. (1998b) found greater separation of individual estuaries than the current study, but the estuaries in their study were separated by distances in excess of $200 \mathrm{~km}$. In contrast, the minimum distance between any 2 estuaries sampled in the present study was $\sim 25 \mathrm{~km}$ and the maximum distance was $\sim 140 \mathrm{~km}$. Greater distances among estuaries may result in greater environmental differences between estuaries and therefore stronger differences in elemental signatures.

Differences in the elemental composition of otoliths of fish were also found at the spatial scale of sites within an estuary. Variation among sites within an estuary has been found in some studies (e.g. Thorrold et al. 1998b), but not in others (e.g. Thorrold et al. 1997). Frequently, however, samples are pooled from multiple sites and therefore variation at the smaller spatial scale is unknown (e.g. Gillanders \& Kingsford 1996).

Although few studies have determined whether differences in elemental composition of otoliths of fish occur among estuaries, many studies have found differences in elemental composition among locations and these have been used in infer differences in stock structure (Edmonds et al. 1989, 1991, 1992, Campana et al. 1994, 1995, Campana \& Gagne 1995, Begg et al. 1998), pollution regimes (Dove \& Kingsford 1998) and natural tags of area of origin for juveniles (Gillanders \& Kingsford 1996, Thorrold et al. 1998a). Some of these studies have also sampled at smaller spatial scales (sites within a location usually separated by hundreds of metres to kilometres), but results are mixed in that some studies have found within location differences (e.g. Kingsford \& Gillanders in press), whereas others have found little variation among sites within a location (e.g. Dove \& Kingsford 1998). A recent study also found considerable variation in elemental composition of otoliths among depth strata with concentrations generally greatest in fish collected from shallow water (Kingsford \& Gillanders in press). Depth strata were separated by tens of metres, suggesting there may be variation in elemental composition across very short distances. Spatial differences in elemental fingerprints 

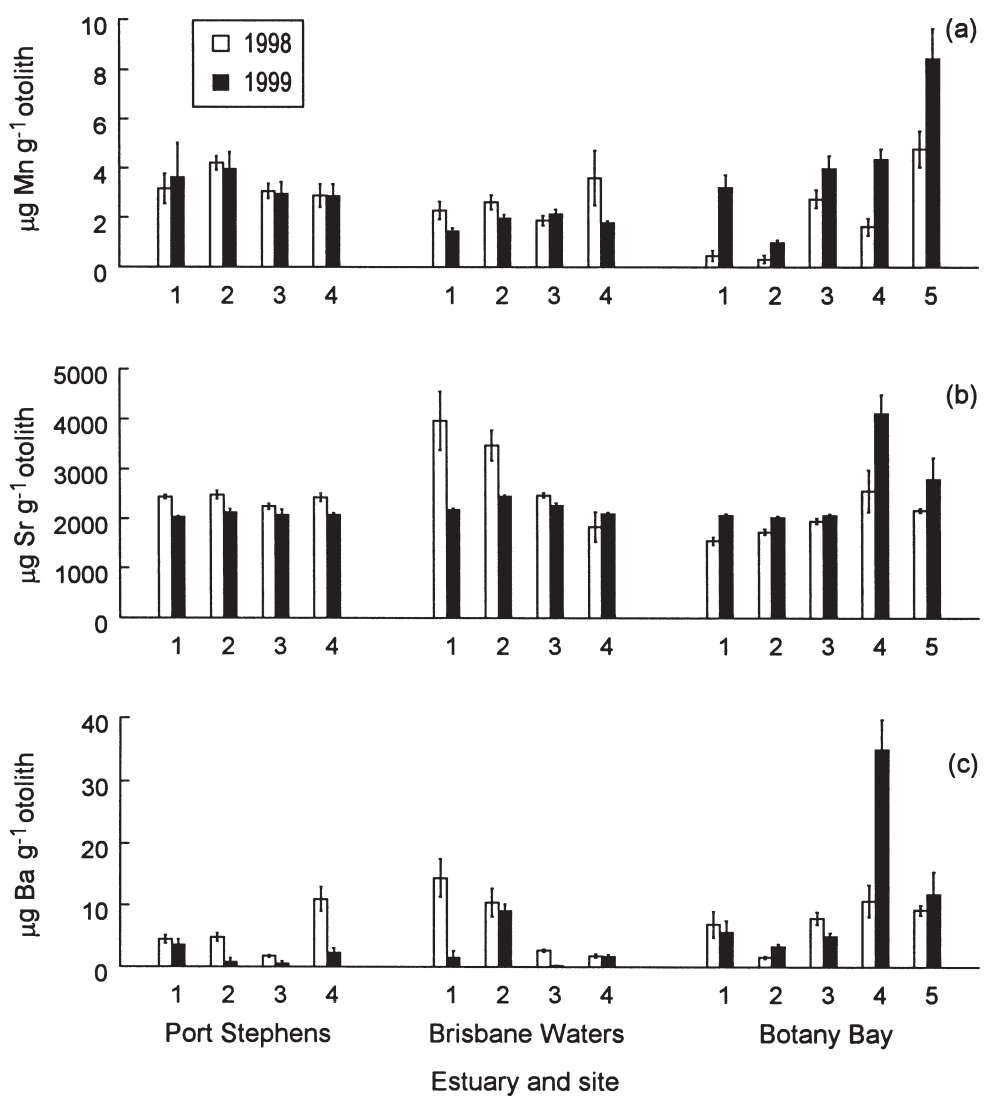

Fig. 4. Pelates sexlineatus. Mean $( \pm \mathrm{SE})$ concentration of (a) $\mathrm{Mn},(\mathrm{b}) \mathrm{Sr}$ and (c) Ba in otoliths of juvenile trumpeter at multiple sites within each of 3 estuaries along the coast of New South Wales, Australia. Fish were collected in 1998 and 1999 are likely to vary depending on the species. For example, differences among sites may be greater for fish that recruit well into estuaries (e.g. Pelates sexlineatus) than for fish which occur on reefs near the entrance to estuaries (e.g. Parma microlepis).

Despite differences in elemental composition of otoliths at a range of spatial scales, the mechanisms generating these differences are not well understood. Water chemistry is likely to vary considerably among estuaries and may be influenced by the presence of rivers and associated freshwater input, oceanography (e.g. estuarine plumes and currents), topographic forcing (of plumes and mixing), and the level of industry and urban development (e.g. sewage outfalls, drainage) (Grimes \& Kingsford 1996, Kingsford \& Suthers 1996). These factors are not only likely to influence the concentration of elements in the water, but also the salinity and temperature of the water mass and may vary along the length of an estuary. Few studies have investigated the relationship between ambient levels of elements and concentration in the otolith, particularly in marine systems. We have no information on ambient concentrations of elements in different estuaries for the current study. Thorrold et al. (1998a) found that the ratio of metal:Ca

Table 4. Results of ANOVA for individual elements in otoliths of juvenile trumpeter collected in 2 years (1998 and 1999$)$ at 4 to 5 sites within each of 3 estuaries. Each estuary was analysed separately. Cochran's tests were used to test homogeneity of variances; the data remained heterogeneous after transformation for Mn and Ba in Brisbane Waters, and Sr in all estuaries. Analyses were made on $\ln (x+1)$-transformed data. $p$-values of 0.000 indicate $p<0.001$

\begin{tabular}{|c|c|c|c|c|c|c|c|c|c|c|c|}
\hline \multirow[t]{2}{*}{ Source } & \multicolumn{4}{|c|}{ Port Stephens (PS) } & \multicolumn{3}{|c|}{ Brisbane Waters (BW) } & \multicolumn{4}{|c|}{ Botany Bay (BB) } \\
\hline & $\mathrm{df}$ & MS & $F$ & $\mathrm{p}$ & MS & $F$ & $\mathrm{p}$ & $\mathrm{df}$ & MS & F & $\mathrm{p}$ \\
\hline \multicolumn{12}{|l|}{ Mn } \\
\hline Year & 1 & 0.012 & 2.85 & 0.190 & 0.387 & 3.33 & 0.165 & 1 & 6.404 & 19.58 & 0.012 \\
\hline Site & 3 & 0.153 & 37.17 & 0.007 & 0.078 & 0.67 & 0.625 & 4 & 4.541 & 13.89 & 0.013 \\
\hline Year $\times$ Site & 3 & 0.004 & 0.04 & 0.988 & 0.116 & 2.55 & 0.073 & 4 & 0.327 & 3.87 & 0.007 \\
\hline Error & 32 & 0.098 & & & 0.046 & & & 60 & 0.084 & & \\
\hline \multicolumn{12}{|l|}{$\mathbf{S r}$} \\
\hline Year & 1 & 0.208 & 45.52 & 0.007 & 0.368 & 1.31 & 0.335 & 1 & 1.068 & 9.94 & 0.034 \\
\hline Site & 3 & 0.007 & 1.55 & 0.364 & 0.427 & 1.52 & 0.369 & 4 & 0.718 & 6.68 & 0.047 \\
\hline Year $\times$ Site & 3 & 0.005 & 0.89 & 0.459 & 0.280 & 5.24 & 0.005 & 4 & 0.107 & 3.17 & 0.020 \\
\hline Error & 32 & 0.005 & & & 0.053 & & & 60 & 0.034 & & \\
\hline \multicolumn{12}{|l|}{ Ba } \\
\hline Year & 1 & 8.654 & 11.27 & 0.044 & 7.045 & 2.92 & 0.186 & 1 & 1.166 & 0.86 & 0.407 \\
\hline Site & 3 & 2.363 & 3.08 & 0.190 & 5.212 & 2.16 & 0.272 & 4 & 6.004 & 4.41 & 0.090 \\
\hline Year $\times$ Site & 3 & 0.768 & 3.41 & 0.029 & 2.411 & 13.39 & 0.000 & 4 & 1.362 & 7.75 & 0.000 \\
\hline Error & 32 & 0.225 & & & 0.180 & & & 60 & 0.176 & & \\
\hline
\end{tabular}


(a)

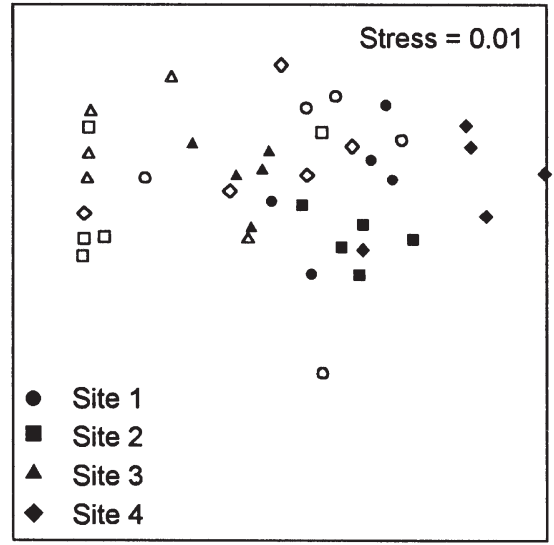

(b)

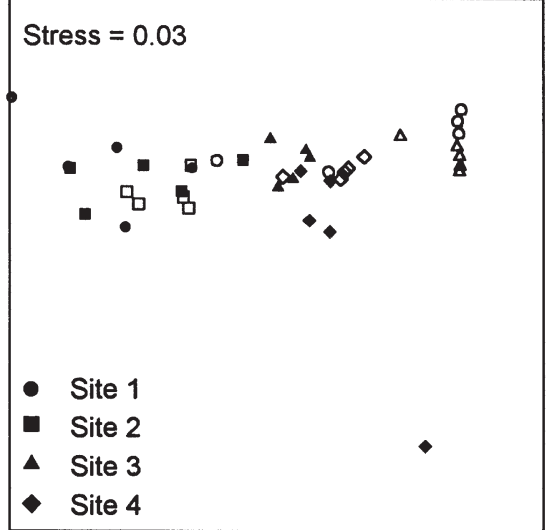

(c)

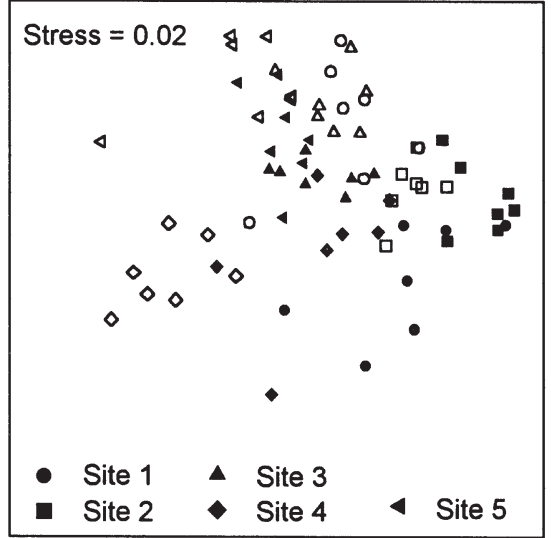

Fig. 5. MDS ordinations of multi-element fingerprints for Pelates sexlineatus collected from multiple sites in (a) Port Stephens, (b) Brisbane Waters and (c) Botany Bay. Closed and open symbols denote fish collected in 1998 and 1999 respectively. Stress values are shown on each plot

of some elements (e.g. Ba, Mg and $\mathrm{Sr}$ ) was correlated with the metal:Ca ratios in ambient river water, but no relationship was found for other elements (e.g. Mn). Chemical marking studies using $\mathrm{Sr}$ have also found a relationship between $\mathrm{Sr}$ concentration in otoliths (and bone) and ambient Sr concentrations (Gallahar \&
Table 5. Results of ANOSIM of Mn, Sr and Ba in otoliths of juvenile Pelates sexlineatus collected at small scales (hundreds of metres to $6 \mathrm{~km}$ ) in each of 3 estuaries over $2 \mathrm{yr}$. $\mathrm{p}$-values of 0.000 indicate $\mathrm{p}<0.001$

\begin{tabular}{|lcc|}
\hline Source & Global $R$ & $\mathrm{p}$ \\
\hline Port Stephens & & \\
Year & 0.514 & 0.000 \\
Site & 0.356 & 0.000 \\
Brisbane Waters & & \\
Year & 0.588 & 0.000 \\
Site & 0.502 & 0.000 \\
Botany Bay & & \\
Year & 0.443 & 0.000 \\
Site & 0.519 & 0.000 \\
\hline
\end{tabular}

Kingsford 1996, Pollard et al. 1999). Geffen et al. (1998), however, found an inverse relationship between exposure and rate of lead incorporation in otoliths. These studies suggest that the relationship between levels of elements in the surrounding water and the concentration in the otolith appears to vary greatly by element.

Salinity and temperature of ambient water may also interact with levels of elements in the water to affect otolith composition. Although relatively good positive correlations exist between the amount of $\mathrm{Sr}$ in the water and salinity, not all studies have found that fish from different salinities show differences in otolith Sr. For example, Chesney et al. (1998) found no relationship between $\mathrm{Sr}$ concentration and either salinity $(20$, $26,33.4 \mathrm{ppt})$ or temperature $\left(18,22,26^{\circ} \mathrm{C}\right)$, whereas Fowler et al. (1995a) found that differences in salinity $(26,35 \mathrm{ppt})$ lead to subtle differences in the concentration of some elements, notably Mn. Relationships between $\mathrm{Sr}$ in otoliths and salinity appear stronger where lower ranges of salinity including freshwater are used (Kalish 1990, Secor 1992), suggesting a possible threshold effect after which salinity has no effect on levels of $\mathrm{Sr}$ in the otolith. Temperature effects on elemental composition were stronger than salinity effects in Fowler et al.'s (1995a) study, but because both $\mathrm{Sr}$ and Ca levels in the otolith varied with temperature it was suggested that $\mathrm{Sr} / \mathrm{Ca}$ ratios would be poor indicators of water temperature. Salinity and temperature are likely to vary within and among estuaries; further research is needed in both controlled laboratory studies and the field to determine possible effects on otolith composition.

Other factors such as diet, growth rates, ontogenetic and physiological effects have also been found to influence otolith composition in some species of fish (Kalish 1989, 1991, Sadovy \& Severin 1992, Fowler et al. 1995b, Limburg 1995). We cannot discount these factors as possible determinants of otolith composition of trum- 
Table 6. Results of discriminant function analyses for which juvenile trumpeter are classified to their site of recruitment within each of 3 estuaries based on elemental fingerprints ( $\mathrm{Mn}, \mathrm{Sr}, \mathrm{Ba}$ ) of otoliths. Each estuary was analysed separately. The percentage of fish classified to each estuary is shown for collections made in 1998, 1999 and both years. The discriminant functions were developed using a cross validation approach for the fish being classified. Bold values indicate percent of fish correctly classified to their recruitment sites

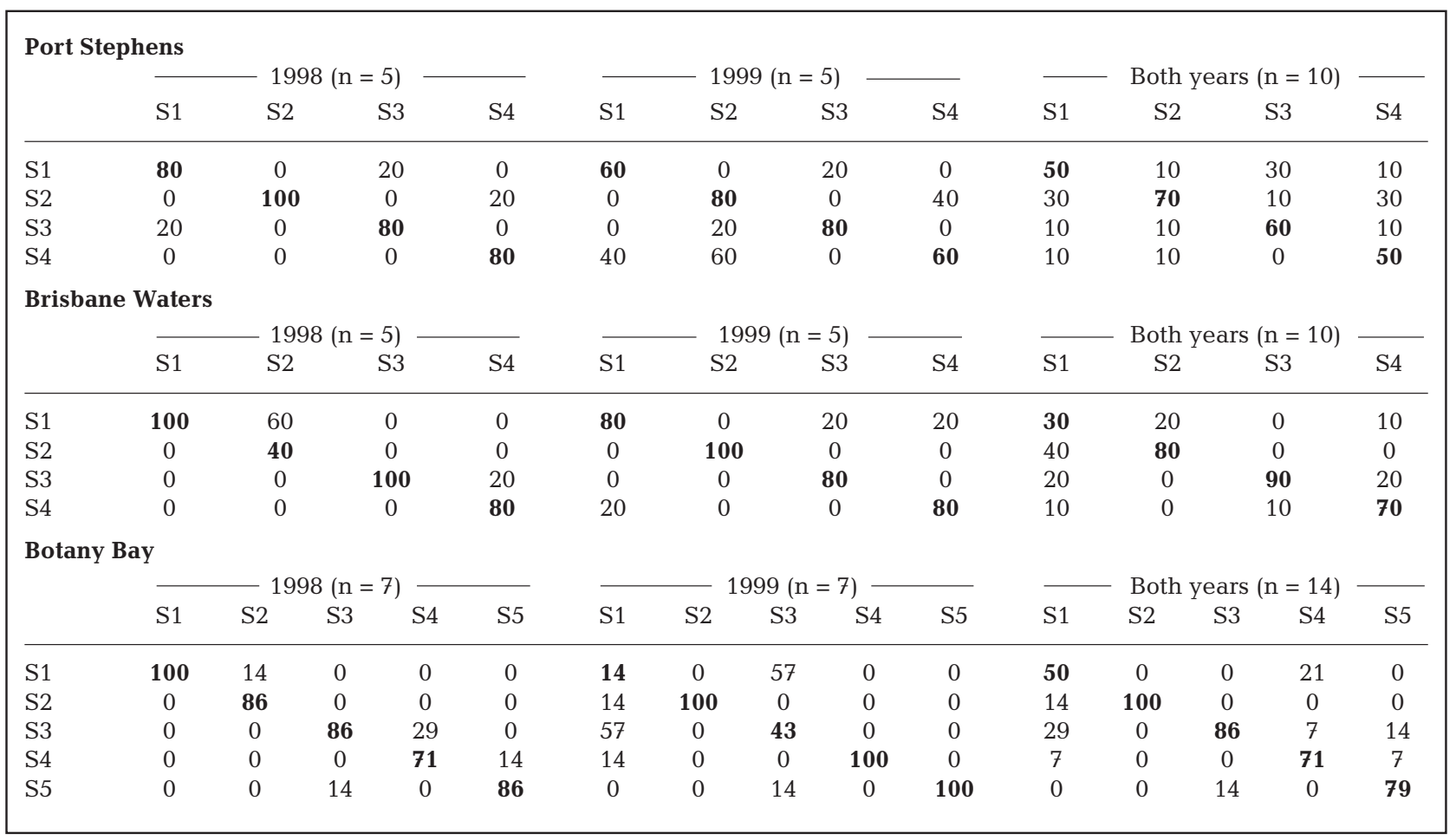

peter, although ontogenetic effects were minimised by analysing otoliths of fish of similar sizes. Physiological effects resulting from reproductive activity are also thought to be minimal because only juvenile fish were analysed. Further work is needed to understand the mechanisms that may lead to differences in element composition of otoliths, but as noted by Thorrold et al. (1998a), it is not necessary to fully understand the mechanisms before using elemental fingerprints as natural tags of 'nursery' habitats (see also Campana et al. 1994).

\section{Temporal differences in elemental composition of otoliths}

The elemental composition of otoliths of fish varied between years, suggesting that either the water chemistry (e.g. elements in the water, temperature and salinity) or ontogenetic and physiological effects may vary among years. We suggest that water chemistry is most likely to vary among years, because all fish used in the current study were immature and of a similar size. The most dramatic variation between years was seen for Mn in otoliths of fish collected from the north- ernmost estuary, where a 20 - to 30 -fold increase was seen in the second year. Although variation in elemental composition of otoliths on an annual basis has been reported by Milton et al. (1997), many studies involve no temporal sampling. Smaller scale temporal sampling was done by Thorrold et al. (1998a), who sampled sites in each of 2 months (August and October). They found that a discriminant function generated from the fish collected in August was able to classify the fish collected in October with greater than $80 \%$ success, indicating little variation in elemental composition over a 2 mo time period. The lack of temporal variation in elemental fingerprints found by Thorrold et al. (1998a) should not be interpolated to longer time scales. It is possible that conditions (e.g. rainfall etc.) remained similar during their study and, therefore, a lack of variation may be expected. Physical events of a continuous or press nature (sensu Glasby \& Underwood 1996) are more likely to vary among years, for example, a change in southern oscillation (ENSO) conditions can create wet or dry summer periods that may influence estuarine waters and therefore otolith microchemistry among years. Temporal variation in elemental composition of otoliths may pose problems for studies determining which estuary adult fish have come 
from, especially if juveniles are collected during a single time period and adults do not come from the same year class as the juveniles.

Changes in the amount of freshwater run-off within and between years may influence elemental composition of otoliths of juvenile fish, particularly with respect to elements such as Sr which are known to change with salinity (Chesney et al. 1998). Freshwater input is likely to have a major impact on estuarine systems, but may have less of an impact on offshore locations, as the depth of low salinity wedges in estuaries decreases with distance from the riverine source (e.g. Botany Bay, Kingsford \& Suthers 1996). Local bathymetry within estuaries may also influence plumes of water associated with freshwater input. Milton et al. (1997) considered that inter-annual differences in otolith composition were unlikely to be related to seasonal changes in freshwater input because fish were spawned during the same season each year. Although fish collected as part of our study were collected during the same season each year, the amount of freshwater run-off was considerably greater in the second year of the study (Bureau of Meteorology Monthly Rainfall Review, Canberra; Fig. 1) and therefore the concentration of elements in the water may also vary among years. Strontium, for example, was lower in otoliths of trumpeter from 2 of the 3 estuaries in the second year where freshwater input was greater than the previous year. Again, the mechanisms generating temporal differences are not well understood and require further study.

\section{Use of elemental fingerprints as natural tags to infer 'nursery' habitat of adults}

Although many studies have shown that large numbers of juvenile fish are found in estuarine habitats, and frequently refer to these as 'nursery' habitats, there are few studies that have shown direct links between putative 'nursery' habitats and adult stocks. Mark-recapture studies provide definitive patterns of movement from nursery to adult habitats, but are generally unfeasible due to the small size of fish in 'nursery' habitats and high mortality rates at early life history stages meaning that large numbers of fish would need to be tagged to ensure that adequate numbers survive to the adult population. There are additional problems concerning the recapture of tagged fish in the adult population. A natural tag, such as the elemental fingerprints of otoliths, ensures that all fish are tagged and thus all adult fish that are recaptured would represent a recovery. In practice, however, this is likely to be complicated by both spatial and temporal differences in elemental fingerprints.
The discriminant functions developed on each year class of recruits showed that on average $75 \%$ of fish were correctly classified to their 'nursery' estuary, whereas when both year classes were combined classification success decreased to $62 \%$, and when the 1998 year class was used to classify the 1999 year class, classification success decreased to less than $50 \%$. Although sample sizes were relatively small, these results do suggest a cautious approach to using elemental fingerprints of juveniles to classify adults that may represent a different year class or to combining multiple year classes of juveniles to determine discriminant functions. There are some estuaries which have higher success rates than others; for example, Tuggerah Lakes averages $95 \%$ classification success over the 2 years and clearly shows promise as an estuary with a very strong elemental fingerprint due in part to the consistently high amounts of $\mathrm{Mn}$ in this estuary. The addition of further elements to the discriminant function and the use of stable isotopes (e.g. Thorrold et al. 1998b) may improve the accuracy of the discriminant functions. Alternatively, the use of nonparametric methods, such as artificial neural networks, may improve the classification success (Thorrold et al. 1998b).

It should also be possible to determine the estuary in which adult fish spent their juvenile life by analysing the juvenile core of adult otoliths (e.g. Gillanders \& Kingsford 1996). This may be done using either laser ablation ICP-MS to sample the juvenile region or by extracting the core from the rest of the otolith followed by solution-based ICP-MS. Using this approach, Gillanders \& Kingsford (1996) suggested that $41 \%$ of blue groper on coastal reefs had spent time in estuaries and moved to the reef, whereas $59 \%$ had recruited to the reef and remained there. Their study, however, used 1 year class of recruits to generate discriminant functions and then classified adult fish that had come from multiple year classes; therefore, their results may vary if adults from the same recruitment year class as the recruits used to determine the discriminant function were used. Despite this, we are confident that recruits that settle into reef habitats can be distinguished from those that settle into estuarine habitats. As far as we are aware, this is the only study that has tracked adult fish moving from estuaries to reef habitat using elemental composition of otoliths. At the scale of among estuaries it also appears that individual estuaries can be distinguished, albeit some better than others (e.g. Tuggerah Lakes). It now appears that adult fish in a coastal fishery could be tracked to their 'nursery' estuary thus enabling numbers of fish originating from different estuaries to be determined. With adequate spatial sampling within an estuary it may also be possible to track adult fish to specific sites within an estu- 
ary and to determine movement among sites for an estuarine species.

In summary, the elemental fingerprints of otoliths of trumpeter show promise as an indicator of the estuary in which the fish spent its juvenile life, but we would caution researchers to ensure that their sampling covers the range of estuaries in which the juvenile fish of interest are found. It also appears necessary to build up a 'library' of elemental fingerprints for each year class of fish or at least to show that there is no variation in elemental composition of otoliths over time. We should now be able to track movements of adults from putative 'nursery habitats' to adult stocks by analysing the juvenile portion of adult otoliths (e.g. Gillanders \& Kingsford 1996). In addition, we can calculate the numbers of fish from a coastal fishery that have moved out from different estuaries. This has major implications for not only fisheries management, but also for the designation of possible marine protected areas.

Acknowledgements. We thank Julian Hughes and Ben Stewart for their assistance with collections of fish and preparation of samples, and Robert McQuilty (RPA hospital) for use of the ICP-MS. The study was conducted while B.M.G. held an ARC postdoctoral fellowship and was funded by an ARC grant and the University of Sydney through research funding. Comments by Sean Connell significantly improved an earlier draft of the manuscript.

\section{LITERATURE CITED}

Begg GA, Cappo M, Cameron DS, Boyle S, Sellin MJ (1998) Stock discrimination of school mackerel, Scomberomorus munroi, in coastal waters of eastern Australia by analysis of minor and trace elements in whole otoliths. Fish Bull 96:653-666

Bell JD, Pollard DA (1989) Ecology of fish assemblages and fisheries associated with seagrasses. Elsevier, Amsterdam

Bell JD, Worthington DG (1993) Links between estuaries and coastal rocky reefs in the lives of fishes from south-eastern Australia. In: Battershull CN, Schiel DR, Jones GP, Creese RG, MacDiarnid AB (eds) Proceedings of the Second International Temperate Reef Symposium, Auckland, NIWA Marine, Wellington, p 85-91

Campana SE, Gagne JA (1995) Cod stock discrimination using ICPMS elemental assays of otoliths. In: Secor DH, Dean JM, Campana SE (eds) Recent developments in fish otolith research. University of South Carolina Press, Columbia, SC, p 671-691

Campana SE, Neilson JD (1985) Microstructure of fish otoliths. Can J Fish Aquat Sci 42:1014-1032

Campana SE, Fowler AJ, Jones CM (1994) Otolith elemental fingerprinting for stock discrimination of Atlantic cod (Gadus morhua) using laser ablation ICPMS. Can J Fish Aquat Sci 51:1942-1950

Campana SE, Gagne JA, McLaren JW (1995) Elemental fingerprinting of fish otoliths using ID-ICPMS. Mar Ecol Prog Ser 122:115-120

Chesney EJ, McKee BM, Blanchard T, Chan LH (1998) Chemistry of otoliths from juvenile menhaden Brevoortia patronus: evaluating strontium, strontium:calcium and stron- tium isotope ratios as environmental indicators. Mar Ecol Prog Ser 171:261-273

Clarke KR (1993) Non-parametric multivariate analyses of changes in community structure. Aust J Ecol 18:117-143

Dove SG, Kingsford MJ (1998) Use of otoliths and eye lenses for measuring trace-metal incorporation in fishes: a biogeographic study. Mar Biol 130:377-387

Dove SG, Gillanders BM, Kingsford MJ (1996) An investigation of chronological differences in the deposition of trace metals in the otoliths of two temperate reef fishes. J Exp Mar Biol Ecol 205:15-33

Edmonds JS, Moran MJ, Caputi N (1989) Trace element analysis of fish sagittae as an aid to stock identification: pink snapper (Chrysophrys auratus) in Western Australian waters. Can J Fish Aquat Sci 46:50-54

Edmonds JS, Caputi N, Morita M (1991) Stock discrimination by trace-element analysis of otoliths of orange roughy (Hoplostethus atlanticus), a deep-water marine teleost. Aust J Mar Freshw Res 42:383-389

Edmonds JS, Lenanton RCJ, Caputi N, Morita M (1992) Trace elements in the otoliths of yellow-eye mullet (Aldrichetta forsteri) as an aid to stock identification. Fish Res 13:39-51

Engelman L (1998) Discriminant analysis. In SYSTAT 8.0 Statistics. SPSS Inc, Chicago

Fowler AJ, Campana SE, Jones CM, Thorrold SR (1995a) Experimental assessment of the effect of temperature and salinity on elemental composition of otoliths using laser ablation ICPMS. Can J Fish Aquat Sci 52:1431-1441

Fowler AJ, Campana SE, Jones CM, Thorrold SR (1995b) Experimental assessment of the effect of temperature and salinity on elemental composition of otoliths using solution-based ICPMS. Can J Fish Aquat Sci 52:1421-1430

Gallahar NK, Kingsford MJ (1996) Factors influencing Sr/Ca ratios in otoliths of Girella elevata: an experimental investigation. J Fish Biol 48:174-186

Geffen AJ, Pearce NJG, Perkins WT (1998) Metal concentrations in fish otoliths in relation to body composition after laboratory exposure to mercury and lead. Mar Ecol Prog Ser 165:235-245

Gillanders BM, Kingsford MJ (1996) Elements in otoliths may elucidate the contribution of estuarine recruitment to sustaining coastal reef populations of a temperate reef fish. Mar Ecol Prog Ser 141:13-20

Glasby TM, Underwood AJ (1996) Sampling to differentiate between pulse and press perturbations. Environ Monit Assess 42:241-252

Grimes CB, Kingsford MJ (1996) How do riverine plumes of different sizes influence fish larvae: do they enhance recruitment? Mar Freshw Res 47:191-208

Kalish JM (1989) Otolith microchemistry: validation of the effects of physiology, age and environment on otolith composition. J Exp Mar Biol Ecol 132:151-178

Kalish JM (1990) Use of otolith microchemistry to distinguish the progeny of sympatric anadromous and non-anadromous salmonids. Fish Bull 88:657-666

Kalish JM (1991) Determinants of otolith chemistry: seasonal variation in the composition of blood plasma, endolymph and otoliths of bearded rock cod Pseudophycis barbatus. Mar Ecol Prog Ser 74:137-159

Kingsford MJ, Gillanders BM (in press) Variation in concentrations of trace elements in the otoliths and eye lenses of a temperate reef fish, Parma microlepis: comparisons by depth, spatial scale and age. Mar Biol

Kingsford MJ, Suthers IM (1996) The influence of tidal phase on patterns of ichthyoplankton abundance in the vicinity of an estuarine front, Botany Bay, Australia. Estuar Coast Shelf Sci 43:33-54 
Limburg KE (1995) Otolith strontium traces environmental history of subyearling American shad Alosa sapidissima. Mar Ecol Prog Ser 119:25-35

Milton DA, Chenery SR, Farmer MJ, Blaber SJM (1997) Identifying the spawning estuaries of the tropical shad, terubok Tenualosa toli, using otolith microchemistry. Mar Ecol Prog Ser 153:283-291

Pollard DA (1984) A review of ecological studies on seagrassfish communities, with particular reference to recent studies in Australia. Aquat Bot 18:3-42

Pollard MJ, Kingsford MJ, Battaglene SC (1999) Chemical marking of juvenile snapper, Pagrus auratus (Sparidae), by incorporation of strontium into dorsal spines. Fish Bull 97:118-131

Sadovy Y, Severin KP (1992) Trace elements in biogenic aragonite: correlation of body growth rate and strontium levels in the otoliths of the white grunt, Haemulon plumieri (Pisces: Haemulidae). Bull Mar Sci 50:237-257

Secor DH (1992) Application of otolith microchemistry analy-

Editorial responsibility: Antony Underwood (Contributing Editor), Sydney, Australia sis to investigate anadromy in Chesapeake Bay striped bass Morone saxatilis. Fish Bull 90:798-806

Thorrold SR, Jones CM, Campana SE (1997) Response of otolith microchemistry to environmental variations experienced by larval and juvenile Atlantic croaker (Micropogonias undulatus). Limnol Oceanogr 42:102-111

Thorrold SR, Jones CM, Campana SE, McLaren JW, Lam JWH (1998a) Trace element signatures in otoliths record natal river of juvenile American shad (Alosa sapidissima). Limnol Oceanogr 43:1826-1835

Thorrold SR, Jones CM, Swart PK, Targett TE (1998b) Accurate classification of juvenile weakfish Cynoscion regalis to estuarine nursery areas based on chemical signatures in otoliths. Mar Ecol Prog Ser 173:253-265

Underwood AJ (1997) Experiments in ecology. Their logical design and interpretation using analysis of variance. Cambridge University Press, Cambridge

Winer BJ, Brown DR, Michels KM (1991) Statistical principles in experimental design. McGraw-Hill, Inc, New York

Submitted: July 26, 1999; Accepted: December 22, 1999

Proofs received from author(s): July 3, 2000 